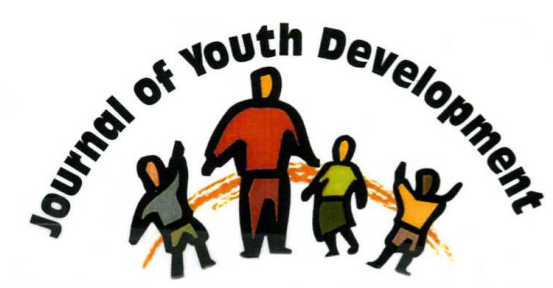

Bridging Research \& Practice

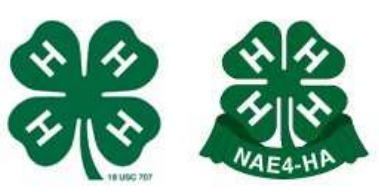

\title{
Service-Learning and Leadership Life Skills: An Experimental Study
}

\author{
B. Darlene Locke \\ Texas A\&M University \\ Brownwood, TX \\ dlocke@ag.tamu.edu \\ Barry Boyd \\ Texas A\&M University \\ College Station, TX \\ b-boyd@tamu.edu \\ Steven Fraze \\ Texas Tech University \\ Lubbock, TX \\ Steven.Fraze@TTU.EDU \\ Jeff W. Howard \\ Texas A\&M University \\ College Station, TX \\ j-howard@tamu.edu
}




\section{JOURNAL OF YOUTH DEVELOPMENT \\ bridging research and practice

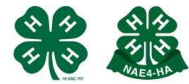

Volume 2, Number 1, Summer 2007

Article 0701FA004

\section{Service-Learning and Leadership Life Skills: An Experimental Study}

B. Darlene Locke, Barry Boyd, Jeff W. Howard

Texas A\&M University

Steven Fraze

Texas Tech University

Abstract: This study examined the effect of service activities on the development of leadership life skills in youth and (queried) if having a reflection component as part of the activity makes a difference. Additionally, the study examined the impact of selected demographics including age, gender, type of service completed monthly and 4-H membership on the development of leadership life skills. Participants in the study were from two samples. One group represented the El Paso National Youth Service Day, the other represented the District 11 4-H Leadership Lab in Branham, Texas. Participants were randomly assigned to a control (no reflection) or treatment (with reflection) group. Youth participants self rated their leadership life skills using a 33-question post-test only questionnaire. Demographics were reported in nine additional questions.

The major findings of the study are as follows: 1) Overall, the participants reported their perceived leadership life skills to be high in four of the five subscales; 2) The inclusion of a reflection component did not significantly affect perceived leadership life skills; 3) Type of service, whether direct or indirect, had a significant impact on perceived leadership life skills; 4) 4-H membership had a significant impact on the Personal Leadership Development subscale. 


\section{Introduction}

In 1984 , only $27 \%$ of all high schools reported having students involved in community service and $9 \%$ reported service-learning activities. By 1999 , those numbers rose to $83 \%$ and $46 \%$ respectively (National Center for Education Statistics, 1999). The Corporation for National and Community Service in March, 2006 reported that "10.6 million students nationwide, or 38 percent of students between the ages of 12 and 18, have participated in school-based service" (Corporation for National and Community Service, 2006). Reported service activities are being conducted as extensions of the classroom and outside of the classroom through communitybased organizations.

The diversity of service activities and participants has resulted in recent studies attempting to identify and separate service-learning and community service. The National Student ServiceLearning and Community Service Survey (National Center for Education Statistics, 1999) defined service-learning as curriculum-based community service that integrates classroom instruction with community service activities. Community service refers to those activities that are noncurriculum-based and are recognized by and/or arranged through the school.

Service activities performed by youth not only benefit the recipient, but the participant as well. Students engaged in service projects learn about themselves, have opportunities for career exploration, experience group dynamics and goal setting, practice their communication skills, and feel valued in the community in which they serve. These service activities provide youth with the opportunity to use newly gained skills and knowledge in real-life situations in their own communities (Close Up Foundation, 1995).

The combined efforts of service learning or community service with a structured program such as the 4-H and Youth Development Program of Cooperative Extension has the opportunity to provide youth with service projects that are real, meaningful, and that will have measurable results in the areas of life skills attainment. As 4-H programs are typically offered in an informal setting, rather than a classroom, service activities tend to lean more toward the community service type versus service-learning.

4-H offers youth supervised independence, a sense of belonging with a positive group, a spirit of generosity toward others and a wide variety of opportunities to master life challenges (National 4-H Headquarters, 2006). This is achieved through participation in project learning experiences and service activities. Often adult volunteers guide or assist youth in their endeavors, creating an intergenerational learning experience.

Involvement in service activities can lead to significant changes in personal leadership and community contribution skills as a result of the service-learning experience. Youth participating in reflection activities as part of their service also indicated higher self-perceived scores in Personal Leadership Development and Contributor to Community (Stafford, 2001). The results were not significant. Therefore, Stafford recommended replicating the research with a larger audience.

\section{Purposes and Objectives}

This study examined the effect of service projects on the development of leadership life skills in youth. It describes whether a reflection component increases the impact of the service experience on the life skills development of youth. Reflection is the critical factor that distinguishes service-learning from community service. The study also examined a possible 
relationship between youth's service experience, their self-perceived leadership life skills, and selected demographic characteristics, including their involvement in the 4- $\mathrm{H}$ and Youth Development Program of Cooperative Extension.

The following objectives were developed to accomplish these purposes:

1. Describe whether personal characteristics impact the development of leadership life skills.

2. Describe whether service projects impact the development of leadership life skills.

3. Describe whether having a reflection component as part of the service project (servicelearning) makes a greater impact than a service project without reflection (community service) in the development of leadership life skills.

4. Describe whether a relationship exists between the youth's service experience, their selfperceived leadership life skills and selected demographic characteristics.

5. Describe whether participation in 4-H and youth development activities has an impact on self-perceived leadership life skills.

\section{Research Design}

The research design used for this study was experimental. A $2 \times 2$ exposure to service learning (no exposure vs. exposure) by treatment (control vs. reflection) between-subjects design was used to conduct the study in conjunction with the El Paso National Youth Service Day on April 12, 2003 and the District 11 4-H Leadership Lab on June 5, 2003.

The study had seven independent variables and five dependent variables. The independent variables for the study included the service experience that youth participated in during the data collection, gender, age, residence, amount of service completed, type of service previously completed, and participation in 4-H club activities.

The dependent variables for the study were the youth's scores in the following leadership life skills categories from the questionnaire developed by the researcher, based on the study by Stafford (2001): Contributor to Community, Creative Problem Solver, Effective Team Skills, Personal Leadership Development, and Self-Directed Learner.

\section{Sample}

Two samples were involved in the research. Sample one involved sixty-nine youth participants of the El Paso National Youth Service Day, April12, 2003. These youth were involved in a community-wide Easter Celebration for families of Fort Bliss Army personnel. The youth represented twenty different youth organizations from the El Paso community.

The second sample involved youth participants of the Texas Cooperative Extension (TCE) District 11, 4-H Leadership Lab conducted on June 5, 2003. District 11 refers to a grouping of eighteen counties located along the Texas Gulf Coast. Leadership Lab is an experientially based leadership education opportunity for 4-H youth ages 13-19. One hundred and fifty-one youth were randomly assigned to one of three different service activities in the Brenham, Texas community.

Thirty-seven youth were assigned to the Brenham State School where they interacted with residents in activities such as line dancing, group games, playing bingo and other board games. Another 41 youth visited residents at area Nursing Homes to create craft items, sing songs and play interactive games. Seventy-three youth visited the Brenham Boys and Girls Club and were involved in many activities from playing basketball and volleyball with club members, to helping 
club members in coloring a wall mural. Other youth assisted in the construction of a storage building while others helped in building and planting a garden.

\section{Descriptive Statistics and Major Findings Delineated by Objective}

The purpose of this study was to:

- describe the population of the study by personal characteristics;

- describe whether service projects impact the development of leadership life skills;

- describe whether having a reflection component as part of the service project makes a greater impact than a service project without reflection in the development of leadership life skills;

- describe whether a relationship exists between the youth's service experience, their selfperceived leadership life skills and selected demographic characteristics;

- describe whether participation in 4-H and youth development activities have an impact on self-perceived leadership life skills.

Due to space limitations of this paper, only gender, age, hours of service, and type of service will be reported.

The gender representation of all participants include; $142(64.5 \%)$ of the participants were female while only 78 (35.5\%) were male. There were 220 youth total. 30 males and 30 females were involved in the National Youth Service Day. There were 103 females and 48 males involved in the District 11, 4-H Leadership Lab.

The age distribution ranged from $12-13$ years (6.4\%) to participants' whose age exceeded 19 $(2.7 \%), 16$ participants $(7.3 \%)$ fell in the $18-19$ years of age group. The largest percentage (44.1\%) of participants was in the $16-17$ year age group and another $39.5 \%$ made up the $14-15$ years of age group. One hundred eighty-four participants (83.6\%) were either $14-15$ or $16-17$ years of age at the time of the study. The six participants aged 19 and over (2.7\%) all came from the El Paso National Youth Service Day.

The amount of service activities completed on a monthly average by participants was also considered. Participants were asked to mark either $0,1-3,4-6,7-9$ or 10 or more hours to indicate the number of hours of service completed on a monthly basis. Seventy-nine participants (35.9\%) indicated they completed $1-3$ hours of service activities each month. A smaller number, $65(29.5 \%)$, indicated their participation was at 4-6 hours per month. Only 15 participants $(6.8 \%)$ reported no service activity on a monthly basis, while a combined $61(27.8 \%)$ participants reported seven or more hours per month of service activities.

The study also investigated the type of service activity completed by participants on a monthly basis. Participants were asked to describe the level of their service activity as either more than $50 \%$ direct (i.e. visiting a nursing home, reading to children), more than $50 \%$ indirect (collecting food, toys or other items for distribution, picking up trash), or does not apply. Ninety-one youth (41.4\%) indicated they were participating in activities that provided direct interaction with the recipients. A larger percentage, 52.3\% (115 participants) were participating in activities that yielded indirect contact with recipients. A small portion, 6.4\%, (14 participants) responded they had not participated in service activities, and therefore answered 'does not apply.' 


\section{Findings Related to Objective Two}

The second objective was to describe whether service projects impact the development of leadership life skills in youth. Youth participants in this study were part of either the National Youth Service Day conducted in El Paso on April 12, 2003 or the District 11, 4-H Leadership Lab conducted in Brenham on June 5, 2003. Participants were asked to respond to thirty-three statements describing leadership life skills in the following five areas:

- Effective Team Skills;

- Creative Problem Solver;

- Personal Leadership Development;

- Self-Directed Learner;

- Contributor to Community.

Analysis of objective two was achieved by computing descriptive statistics on each of the thirtythree questions and further grouping the five subscales and computing descriptive statistics on the groups. The questionnaire included a Likert-type scale to record participants' responses to the thirty-three statements. The scale contained six potential responses: $1=$ Strongly Disagree; 2 = Disagree; 3 = Slightly Disagree; 4 = Slightly Agree; 5 = Agree; $6=$ Strongly Agree.

Table 1

Level of National Youth Service Day and District 11 4-H Leadership Lab Participants' Agreement with Effective Team Skills Statements, 2003, $n=220$

\begin{tabular}{|l|c|c|c|c|c|c|c|c|c|c|c|c|c|}
\hline & \multicolumn{2}{|c|}{$\begin{array}{c}\text { Strongly } \\
\text { Disagree }\end{array}$} & \multicolumn{2}{|c|}{ Disagree } & \multicolumn{2}{c|}{$\begin{array}{c}\text { Slight/y } \\
\text { Disagree }\end{array}$} & \multicolumn{2}{|c|}{$\begin{array}{c}\text { Slight/y } \\
\text { Agree }\end{array}$} & \multicolumn{2}{|c|}{ Agree } & \multicolumn{2}{c|}{$\begin{array}{c}\text { Strongly } \\
\text { Agree }\end{array}$} \\
\hline $\begin{array}{c}\text { Effective Team } \\
\text { Skills }\end{array}$ & $\boldsymbol{f}$ & $\%$ & $\boldsymbol{f}$ & $\%$ & $\boldsymbol{f}$ & $\%$ & $\boldsymbol{f}$ & $\%$ & $\boldsymbol{f}$ & $\%$ & $\boldsymbol{f}$ & $\%$ \\
\hline $\begin{array}{l}\text { I cooperate with } \\
\text { others. }\end{array}$ & 0 & 0 & 3 & 1.4 & 6 & 2.7 & 27 & 12.2 & 101 & 45.7 & 83 & 37.6 \\
\hline $\begin{array}{l}\text { I can get my ideas } \\
\text { across to others. }\end{array}$ & 1 & 0.5 & 3 & 1.4 & 8 & 3.6 & 43 & 19.5 & 100 & 45.2 & 65 & 29.4 \\
\hline $\begin{array}{l}\text { I accept other } \\
\text { people as they are. }\end{array}$ & 1 & 0.5 & 2 & 0.9 & 3 & 1.4 & 28 & 12.7 & 100 & 45.2 & 86 & 38.9 \\
\hline $\begin{array}{l}\text { I can get along with } \\
\text { others who are } \\
\text { different from me. }\end{array}$ & 1 & 0.5 & 0 & 0 & 8 & 3.6 & 17 & 7.7 & 103 & 46.6 & 91 & 41.2 \\
\hline I encourage others. & 0 & 0 & 1 & 0.5 & 5 & 2.3 & 29 & 13.1 & 96 & 43.4 & 89 & 40.3 \\
\hline $\begin{array}{l}\text { I can keep written } \\
\text { records. }\end{array}$ & 6 & 2.7 & 15 & 6.8 & 25 & 11.3 & 45 & 20.4 & 81 & 36.7 & 48 & 21.7 \\
\hline $\begin{array}{l}\text { I can follow } \\
\text { directions. }\end{array}$ & 0 & 0 & 0 & 0 & 5 & 2.3 & 33 & 14.9 & 93 & 42.1 & 89 & 40.3 \\
\hline I trust other people. & 3 & 1.4 & 5 & 2.3 & 14 & 6.3 & 47 & 21.3 & 89 & 40.3 & 62 & 28.1 \\
\hline $\begin{array}{l}\text { I can lead a } \\
\text { discussion. }\end{array}$ & 4 & 1.8 & 5 & 2.3 & 9 & 4.1 & 38 & 17.2 & 92 & 41.6 & 72 & 32.6 \\
\hline
\end{tabular}

Note: Scale 1 = Strongly Disagree; 2 = Disagree; 3 = Slightly Disagree; 4 = Slightly Agree; 5 = Agree; 6 = Strongly Agree; Scale Score for Participants, $M=5.02, S D=0.59$, Min=2.56, $M a x=6.0$ 
For the Effective Team Skills (Table 1) subscale, seventy-eight percent of all the respondents either "agreed" or "strongly agreed" to seven of the nine statements. However, only 59\% responded with "agree" or "strongly agree" to the statement, "I can keep written records." Similarly, only 69\% responded with "agree" or "strongly agree" to the statement, "I trust other people." These two statements received the lowest overall scores in this subscale. Mean scores for participants were $5.02(S D=0.59, \operatorname{Min}=2.56, \operatorname{Max}=6.0)$ for the nine questions combined.

There were five individual questions and descriptive data for the Creative Problem Solver (Table 2) subscale. Seventy-four percent of all the respondents either "slightly agreed" or "agreed" with all five statements. Only $15 \%$ responded "strongly agree" to the combined five statements. The statement "When solving a problem, I generate many possible solutions before making a decision" received 152 (69\%), "slightly agree" or "agree" responses, the lowest frequency of the five statements. The statement, "I solve problems in ways they have never been solved before" received 173 (79\%) "slightly agree" or "agree" responses, the highest frequency of the five statements. Creative Problem Solver had the lowest overall mean, 4.57, $S D=0.66, M i n=1.80$, Max=6.0.

Table 2

Level of National Youth Service Day and District 11 4-H Leadership Lab Participants' Agreement with Creative Problem Solver Statements, 2003, $n=220$

\begin{tabular}{|l|c|c|c|c|c|c|c|c|c|c|c|c|}
\hline & \multicolumn{2}{|c|}{$\begin{array}{c}\text { Strongly } \\
\text { Disagree }\end{array}$} & \multicolumn{2}{c|}{ Disagree } & \multicolumn{2}{c|}{$\begin{array}{c}\text { Slight/y } \\
\text { Disagree }\end{array}$} & \multicolumn{2}{|c|}{$\begin{array}{c}\text { Slight/y } \\
\text { Agree }\end{array}$} & \multicolumn{2}{|c|}{ Agree } & \multicolumn{2}{|c|}{$\begin{array}{c}\text { Strongly } \\
\text { Agree }\end{array}$} \\
\hline $\begin{array}{l}\text { Creative Problem } \\
\text { Solver }\end{array}$ & $\boldsymbol{f}$ & $\%$ & $\boldsymbol{f}$ & $\%$ & $\boldsymbol{f}$ & $\%$ & $\boldsymbol{f}$ & $\%$ & $\boldsymbol{f}$ & $\%$ & $\boldsymbol{f}$ & $\%$ \\
\hline $\begin{array}{l}\text { I solve problems in } \\
\text { ways they have } \\
\text { never been solved } \\
\text { before. }\end{array}$ & 3 & 1.4 & 8 & 3.6 & 28 & 12.7 & 89 & 40.3 & 84 & 38 & 8 & 3.6 \\
\hline $\begin{array}{l}\text { When solving a } \\
\text { problem, I generate } \\
\text { many possible } \\
\text { solutions before } \\
\text { making a decision. }\end{array}$ & 2 & 0.9 & 4 & 1.8 & 13 & 5.9 & 49 & 22.2 & 103 & 46.6 & 49 & 22.2 \\
\hline $\begin{array}{l}\text { I follow a process to } \\
\text { solve a problem. }\end{array}$ & 6 & 2.7 & 12 & 5.4 & 12 & 5.4 & 75 & 33.9 & 80 & 36.2 & 35 & 15.8 \\
\hline $\begin{array}{l}\text { I consider all choices } \\
\text { before solving a } \\
\text { problem. }\end{array}$ & 0 & 0 & 5 & 2.3 & 6 & 2.7 & 55 & 24.9 & 113 & 51.1 & 41 & 18.6 \\
\hline $\begin{array}{l}\text { I clearly define a } \\
\text { problem before } \\
\text { generating possible } \\
\text { solutions. }\end{array}$ & 2 & 0.9 & 6 & 2.7 & 14 & 6.3 & 66 & 29.9 & 99 & 44.8 & 33 & 14.9 \\
\hline & 13 & 1.2 & 35 & 3.2 & 73 & 6.6 & 334 & 30.4 & 479 & 43.5 & 166 & 15.1 \\
\hline
\end{tabular}

Note: Scale 1 = Strongly Disagree; 2 = Disagree; 3 = Slightly Disagree; 4 = Slightly Agree; 5 = Agree; 6 = Strongly Agree; Scale Score for Participants, $M=4.57, S D=0.66$, Min=1.80, Max=6.0

The next subscale was Personal Leadership Development (Table 3). This subscale had the highest overall mean, $5.24(S D=0.51, \operatorname{Min}=2.50, M a x=6.0)$ of the five. Eighty-six percent of all the respondents replied "agree" or "strongly agree" to all six statements. Another $11 \%$ 
responded with "slightly agree" to all six statements. Ninety-seven percent of all respondents indicated "slightly agree", "agree" or "strongly agree" to all six statements. Less than $1 \%$ responded with "strongly disagree" or "disagree" for all six statements.

Ninety-two percent responded "agree" or "strongly agree" to the statement, "Serving others helps me grow as a leader." While only $78 \%$ responded "agree" or "strongly agree" to the statement, "I am positive about my abilities."

The most frequent response, 53\% was "strongly agree" for the statement, "I learn from others." Forty-nine percent responded "agree" to the statements, "Helping others increases my awareness of other's needs," and "Serving others helps me grow as a leader."

Table 3

Level of National Youth Service Day and District 11 4-H Leadership Lab Participants' Agreement with Personal Leadership Statements, 2003, $n=220$

\begin{tabular}{|l|c|c|c|c|c|c|c|c|c|c|c|c|c|}
\hline & \multicolumn{2}{|c|}{$\begin{array}{c}\text { Strongly } \\
\text { Disagree }\end{array}$} & \multicolumn{2}{|c|}{ Disagree } & \multicolumn{2}{c|}{$\begin{array}{c}\text { Slight/y } \\
\text { Disagree }\end{array}$} & \multicolumn{2}{|c|}{$\begin{array}{c}\text { Slight/y } \\
\text { Agree }\end{array}$} & \multicolumn{2}{|c|}{ Agree } & \multicolumn{2}{c|}{$\begin{array}{c}\text { Strongly } \\
\text { Agree }\end{array}$} \\
\hline $\begin{array}{c}\text { Personal } \\
\text { Leadership }\end{array}$ & $\boldsymbol{f}$ & $\%$ & $\boldsymbol{f}$ & $\%$ & $\boldsymbol{f}$ & $\%$ & $\boldsymbol{f}$ & $\%$ & $\boldsymbol{f}$ & $\%$ & $\boldsymbol{f}$ & $\%$ \\
\hline $\begin{array}{l}\text { Helping others } \\
\text { increases my } \\
\text { awareness of } \\
\text { other's needs. }\end{array}$ & 1 & 0.5 & 4 & 1.8 & 3 & 1.4 & 21 & 9.5 & 107 & 48.4 & 84 & 38 \\
\hline I learn from others. & 0 & 0 & 0 & 0 & 4 & 1.8 & 20 & 9 & 80 & 36.2 & 116 & 52.5 \\
\hline $\begin{array}{l}\text { I am positive about } \\
\text { my abilities. }\end{array}$ & 1 & 0.5 & 2 & 0.9 & 6 & 2.7 & 38 & 17.2 & 100 & 45.2 & 73 & 33 \\
\hline $\begin{array}{l}\text { I can be a leader } \\
\text { when I serve } \\
\text { other's needs. }\end{array}$ & 0 & 0 & 0 & 0 & 7 & 3.2 & 17 & 7.7 & 95 & 43 & 101 & 45.7 \\
\hline $\begin{array}{l}\text { Serving others } \\
\text { helps me grow as a } \\
\text { leader. }\end{array}$ & 0 & 0 & 0 & 0 & 1 & 0.5 & 16 & 7.2 & 107 & 48.4 & 96 & 43.4 \\
\hline $\begin{array}{l}\text { I feel comfortable } \\
\text { acting as a leader } \\
\text { when helping } \\
\text { others. }\end{array}$ & 1 & 0.5 & 3 & 1.4 & 8 & 3.6 & 30 & 13.6 & 89 & 40.3 & 89 & 40.3 \\
\hline & 3 & 0.2 & 9 & 0.7 & 29 & 2.2 & 142 & 10.8 & 578 & 43.8 & 559 & 42.3 \\
\hline
\end{tabular}

Note: Scale 1 = Strongly Disagree; 2 = Disagree; 3 = Slightly Disagree; 4 = Slightly Agree; 5 = Agree; 6 = Strongly Agree; Scale Score for Participants, $M=5.24, S D=0.51$, Min=2.50, Max=6.0

There were five individual questions and descriptive data for the Self- Directed Learner (Table 4) subscale. Eighty-two percent of the respondents indicated "agree" or "strongly agree" to all five statements. Ninety-six percent of the respondents indicted "slightly agree," "agree," or "strongly agree" to all five statements. Only $1 \%$ of the respondents indicated "strongly disagree" or "disagree" with the five statements. The overall mean of 5.16 ( $S D=0.55$, Min=2.80, Max=6.0) indicates a favorable response to the Self-Directed Learner subscale. While overall, $82 \%$ of the respondents indicated "agree" or "strongly agree" to all six statements, only $78 \%$ had the same response for the statement, "I understand the significance to life of what I learn." Similarly, only $75 \%$ had the same responses for the statement, "I like to discover new knowledge on my own." 
The statement, "I enjoy learning when my experiences pertain to real life" received $47 \%$, the highest number of "strongly agree" responses in this subscale.

Table 4

Level of National Youth Service Day and District 11 4-H Leadership Lab Participants' Agreement with Self-Directed Learner Statements, 2003, n=220

\begin{tabular}{|l|c|c|c|c|c|c|c|c|c|c|c|c|}
\hline & $\begin{array}{c}\text { Strongly } \\
\text { Disagree }\end{array}$ & Disagree & \multicolumn{2}{|c|}{$\begin{array}{c}\text { Slightly } \\
\text { Disagree }\end{array}$} & \multicolumn{2}{|c|}{$\begin{array}{c}\text { Slight/y } \\
\text { Agree }\end{array}$} & \multicolumn{2}{|c|}{ Agree } & \multicolumn{2}{|c|}{$\begin{array}{c}\text { Strongly } \\
\text { Agree }\end{array}$} \\
\hline $\begin{array}{l}\text { Self-Directed } \\
\text { Learner }\end{array}$ & $\boldsymbol{f}$ & $\%$ & $\boldsymbol{f}$ & $\%$ & $\boldsymbol{f}$ & $\%$ & $\boldsymbol{f}$ & $\%$ & $\boldsymbol{f}$ & $\%$ & $\boldsymbol{f}$ & $\%$ \\
\hline $\begin{array}{l}\text { I use past } \\
\text { experiences when I } \\
\text { am learning } \\
\text { something new. }\end{array}$ & 0 & 0 & 2 & 0.9 & 4 & 1.8 & 23 & 10.4 & 100 & 45.2 & 91 & 41.2 \\
\hline $\begin{array}{l}\text { I like to discover } \\
\text { new knowledge on } \\
\text { my own. }\end{array}$ & 1 & 0.5 & 3 & 1.4 & 11 & 5 & 40 & 18.1 & 92 & 41.6 & 73 & 33 \\
\hline $\begin{array}{l}\text { I understand the } \\
\text { significance to life } \\
\text { of what I learn. }\end{array}$ & 2 & 0.9 & 2 & 0.9 & 4 & 1.8 & 41 & 18.6 & 97 & 43.9 & 74 & 33.5 \\
\hline $\begin{array}{l}\text { I learn more when } \\
\text { I am involved in } \\
\text { the planning } \\
\text { process of the } \\
\text { learning } \\
\text { experience. }\end{array}$ & 0 & 0 & 1 & 0.5 & 5 & 2.3 & 32 & 14.5 & 103 & 46.6 & 79 & 35.7 \\
\hline $\begin{array}{l}\text { I enjoy learning } \\
\text { when my } \\
\text { experiences pertain } \\
\text { to real life. }\end{array}$ & 1 & 0.5 & 0 & 0 & 3 & 1.4 & 18 & 8.1 & 94 & 42.5 & 104 & 47.1 \\
\hline & 4 & 0.4 & 8 & 0.7 & 27 & 2.5 & 154 & 14.0 & 486 & 44.2 & 421 & 38.3 \\
\hline
\end{tabular}

Note: Scale 1 = Strongly Disagree; 2 = Disagree; 3 = Slightly Disagree; 4 = Slightly Agree; 5 = Agree; 6 = Strongly Agree; Scale Score for Participants, $M=5.16, S D=0.55$, Min=2.80, Max=6.0

The Contributor to Community (Table 5) subscale included eight individual questions and descriptive data. The overall mean, $5.21(S D=0.59, \operatorname{Min}=3.25, \operatorname{Max}=6.0)$ was the second highest of the five subscales, indicating a very favorable response. Eighty-three percent of all respondents indicated "agree" or "strongly agree" to all eight statements. Ninety-six percent of all respondents indicated "slightly agree," "agree," or "strongly agree" to all eight statements. Less than $1 \%$ responded "strongly disagree" or "disagree" with all eight statements. The statement "Helping others has influenced the way I live my life" received the lowest percentage, $76 \%$ of "agree" and "strongly agree" responses. The remaining seven statements showed $82 \%$ or more of the respondents with "agree" or "strongly agree" marked.

The statement "I can make a difference in my community" received the highest frequency (105) of "strongly agree" responses. Forty-seven percent of the youth marked this response. Another $46 \%$ responded similarly for the statement, "Having a chance to serve makes me a stronger part of my community." The statement, "Serving others helps me better understand my community" showed a $47 \%$ response rate for "agree". 
Table 5

Level of National Youth Service Day and District 11 4-H Leadership Lab Participants' Agreement with Contributor to Community Statements, 2003, n=220

\begin{tabular}{|l|c|c|c|c|c|c|c|c|c|c|c|c|}
\hline & \multicolumn{2}{|c|}{$\begin{array}{c}\text { Strongly } \\
\text { Disagree }\end{array}$} & \multicolumn{2}{|c|}{ Disagree } & \multicolumn{2}{c|}{$\begin{array}{c}\text { Slight/y } \\
\text { Disagree }\end{array}$} & \multicolumn{2}{|c|}{$\begin{array}{c}\text { Slight/y } \\
\text { Agree }\end{array}$} & \multicolumn{2}{|c|}{ Agree } & \multicolumn{2}{|c|}{$\begin{array}{c}\text { Strongly } \\
\text { Agree }\end{array}$} \\
\hline $\begin{array}{l}\text { Contributor to } \\
\text { Community }\end{array}$ & $\boldsymbol{f}$ & $\%$ & $\boldsymbol{f}$ & $\%$ & $\boldsymbol{f}$ & $\%$ & $\boldsymbol{f}$ & $\%$ & $\boldsymbol{f}$ & $\%$ & $\boldsymbol{f}$ & $\%$ \\
\hline $\begin{array}{l}\text { I feel a } \\
\text { responsibility to } \\
\text { serve my } \\
\text { community. }\end{array}$ & 0 & 0 & 1 & 1 & 4 & 2 & 33 & 15 & 98 & 44 & 84 & 38 \\
\hline $\begin{array}{l}\text { Helping others } \\
\text { influences how I } \\
\text { live my life. }\end{array}$ & 1 & 0.5 & 4 & 2 & 8 & 4 & 39 & 18 & 91 & 41 & 77 & 35 \\
\hline $\begin{array}{l}\text { Having a chance to } \\
\text { serve makes me a } \\
\text { stronger part of my } \\
\text { community. }\end{array}$ & 0 & 0 & 1 & 1 & 3 & 1 & 27 & 12 & 87 & 39 & 102 & 46 \\
\hline $\begin{array}{l}\text { Community service } \\
\text { makes me think } \\
\text { about real life in } \\
\text { new ways. }\end{array}$ & 0 & 0 & 5 & 2 & 5 & 2 & 28 & 13 & 84 & 38 & 98 & 44 \\
\hline $\begin{array}{l}\text { Serving others } \\
\text { helps me better } \\
\text { understand my } \\
\text { community. }\end{array}$ & 0 & 0 & 2 & 1 & 4 & 2 & 32 & 15 & 103 & 47 & 79 & 36 \\
\hline $\begin{array}{l}\text { I can make a } \\
\text { difference in my } \\
\text { community. }\end{array}$ & 1 & 0.5 & 0 & 0 & 3 & 1 & 17 & 7.7 & 94 & 43 & 105 & 48 \\
\hline $\begin{array}{l}\text { I will continue to } \\
\text { volunteer after } \\
\text { high school. }\end{array}$ & 0 & 0 & 0 & 0 & 7 & 3 & 30 & 14 & 88 & 40 & 95 & 43 \\
\hline $\begin{array}{l}\text { A leader should be } \\
\text { required to serve } \\
\text { his/her community. }\end{array}$ & 2 & 0.9 & 0 & 0 & 11 & 5 & 22 & 10 & 91 & 41 & 94 & 43 \\
\hline & 4 & 0.2 & 13 & 0.7 & 45 & 2.6 & 228 & 13.0 & 736 & 41.8 & 734 & 41.7 \\
\hline
\end{tabular}

Note: Scale 1 = Strongly Disagree; 2 = Disagree; 3 = Slightly Disagree; 4 = Slightly Agree; 5 = Agree;

$6=$ Strongly Agree; Scale Score for Participants, $M=5.21, S D=0.59$, Min=3.25, Max=6.0

The five subscale means ranged from a high of 5.24, Personal Leadership Development, to a low of 4.57, Creative Problem Solver. Contributor to Community had an overall mean of 5.21; SelfDirected Learner, 5.16; and Effective Team Skills, 5.02.

\section{Findings Related to Objective Three}

The third objective sought to describe whether having a reflection component as part of the service project makes a greater impact than a service project without reflection in the development of leadership life skills. An independent samples t-test comparing the means of each of the five subscales, Effective Team Skills, Creative Problem Solver, Personal Leadership 
Development, Self-Directed Learner and Contributor to Community, yielded no significant difference between the reflection (treatment) and no reflection (control) groups. The presence of a reflection component to the service activity did not significantly increase leadership life skills in the participants as shown in Table 6.

Table 6

The Impact of Reflection in the Development of Leadership Life Skills by Participants in a Service Activity at National Youth Service Day, El Paso and District 11 Leadership Lab, Brenham, TX, 2003, n=220

\begin{tabular}{|l|c|c|c|c|c|c|}
\hline & \multicolumn{2}{|c|}{$\begin{array}{c}\text { Control: no } \\
\text { reflection }\end{array}$} & \multicolumn{2}{|c|}{$\begin{array}{c}\text { Treatment: } \\
\text { with reflection }\end{array}$} & \multicolumn{2}{|l|}{} \\
\cline { 2 - 7 } & $M$ & $S D$ & $M$ & $S D$ & $t$-value & Sig \\
\hline Creative Problem Solver & 4.63 & & 4.49 & 0.62 & 1.55 & 0.123 \\
\hline $\begin{array}{l}\text { Personal Leadership } \\
\text { Development }\end{array}$ & 5.28 & 0.46 & 5.19 & 0.58 & 1.4 & 0.162 \\
\hline Self-Directed Learner & 5.2 & 0.54 & 5.1 & 0.57 & 1.27 & 0.206 \\
\hline Effective Team Skills & 5.06 & 0.55 & 4.98 & 0.64 & 0.98 & 0.328 \\
\hline Contributor to Community & 5.24 & 0.56 & 5.15 & 0.63 & 1.14 & 0.255 \\
\hline
\end{tabular}

$* p<.05$

\section{Finding Related to Objective Four}

The fourth objective of the study was to describe whether a relationship exists between the youth's service experience, their self-perceived leadership life skills and selected demographic characteristics. The service experience refers to whether the service activity was more than $50 \%$ direct contact or more than $50 \%$ indirect contact or no service activity. Direct contact was defined as directly interacting with the people being impacted by the service. Examples include visiting nursing homes, mentoring or tutoring children, or serving meals to the homeless. Indirect service was defined as those activities where the youth had no direct contact with the recipient of the service. Examples include food or clothing drives or cleaning the roadside of trash.

Service experience also refers to the number of hours a youth contributes to service activities on a monthly basis. Youth reported their prior service hours as $0,1-3,4-6,7-9$ or 10 or more hours per month.

Self-perceived leadership life skills refer to the five dependent variables: Effective Team Skills, Creative Problem Solver, Personal Leadership Development, Self-Directed Learner and Contributor to Community. Selected demographics include gender, age, and treatment. A (Multiple Analysis of Variance) MANOVA was used to determine the differences between the five dependent variables and selected independent variables. The use of MANOVA reduces the chance of a Type I error when trying to determine if several groups differ on more than one dependent variable (Gall et al., 1996). The results of the MANOVA are shown in Table 7. Only number of prior service hours and service type showed a significant difference. Gender, age and treatment did not show a significant difference on the development of leadership life skills. 
Table 7

The Impact of Gender, Age, Treatment, Number of Service Hours and Service Type in the Development of Leadership Life Skills by Participants in a Service Activity at National Youth Service Day, El Paso and District 11 Leadership Lab, Brenham, TX, 2003, $n=220$

\begin{tabular}{|l|c|c|c|c|}
\hline \multicolumn{1}{|c|}{ Variable } & $\boldsymbol{d f}$ & $\begin{array}{c}\text { Wilks' } \\
\text { Lambda }\end{array}$ & $\boldsymbol{F}$ & Sig \\
\hline Gender & 1 & 0.966 & 1.48 & 0.197 \\
\hline Age & 6 & 0.987 & 0.54 & 0.743 \\
\hline Treatment & 1 & 0.982 & 0.75 & 0.588 \\
\hline Number of Service Hours & 4 & 0.914 & 3.95 & $.002^{*}$ \\
\hline Service Type & 1 & 0.928 & 3.27 & $.007 *$ \\
\hline
\end{tabular}

*p $<.05$

\section{Findings Related to Objective Five}

The fifth objective of the study was to describe whether participation in 4-H and youth development activities has an impact on self-perceived leadership life skills. An independent samples $\mathrm{t}$-test was used to compare the means on the five leadership life skills for 4-H members $(n=165)$ and non-4-H members $(n=55)$. Descriptive statistics showed the means for non-4-H members to be higher for all five of the leadership life skills subscales. 4-H membership had a significant impact on only one life skill, Personal Leadership Development $(t(1,217)=-2.252$ $\mathrm{p}<.05)$. This is shown in Table 8. Non-4-H members had significantly higher Personal Leadership Development skills than $4-\mathrm{H}$ youth. The effect size of 0.36 for Personal Leadership Development is small (Cohen, 1988) indicating that while statistically significant, it is not readily visible.

Table 8

The Impact of 4-H Membership in the Development of Leadership Life Skills by Participants in a Service Activity at National Youth Service Day, El Paso and District 11 Leadership Lab, Brenham, TX, 2003, n=220

\begin{tabular}{|l|c|c|c|c|c|c|}
\hline \multicolumn{1}{|c|}{ Variable } & 4-H? & $\boldsymbol{M}$ & $\boldsymbol{S D}$ & $\boldsymbol{t}$-value & $\boldsymbol{d}$ & Sig \\
\hline Creative Problem Solver & yes & 4.55 & 0.68 & & & \\
\hline & no & 4.62 & 0.60 & -0.742 & 0.11 & 0.459 \\
\hline $\begin{array}{l}\text { Personal Leadership } \\
\text { Development }\end{array}$ & yes & 5.2 & 0.51 & & & \\
\hline & no & 5.38 & 0.50 & -2.252 & 0.36 & $0.025 *$ \\
\hline Self-Directed Learner & yes & 5.13 & 0.57 & & & \\
\hline & no & 5.25 & 0.49 & -1.398 & 0.23 & 0.163 \\
\hline Effective Team Skills & yes & 4.99 & 0.60 & & & \\
\hline & no & 5.12 & 0.55 & -1.397 & 0.23 & 0.164 \\
\hline Contributor to Community & yes & 5.18 & 0.59 & & & \\
\hline & no & 5.28 & 0.58 & -1.114 & 0.17 & 0.267 \\
\hline
\end{tabular}

$* \mathrm{p}<.05$ 


\section{Conclusions, Implication, and Recommendations}

Objective two of the study was to describe whether service projects impact the development of leadership life skills in youth. Participants were asked to respond to thirty-three statements describing leadership life skills in the following five areas:

- Effective Team Skills

- Creative Problem Solver

- Personal Leadership Development

- Self-Directed Learner

- Contributor to Community

Analysis of objective two was achieved by computing descriptive statistics on each of the thirtythree questions and further grouping the five subscales and computing descriptive statistics on the groups. Results of the data analysis revealed the following for objective two:

1. Overall, the participants rated their self-perceived leadership life skills above average. The means scores for each subscale were greater than 4.57 on a 6-point scale. Personal Leadership Development had the highest mean of 5.24, followed by Contributor to Community at 5.21, Self-Directed Learner at 5.16, Effective Team Skills at 5.02 and Creative Problem Solver had the lowest mean of 4.57.

2. Ninety-five percent of the participants responded Slightly Agree, Agree or Strongly Agree to all 33 statements. Of that 95\%, 79\% of the responses were either Agree or Strongly Agree. This indicates the participants had a very positive view of their leadership skills. This data parallels Stafford (2001) where participants in a similar study rated their leadership life skills high. Specifically, $75-88 \%$ on the average, reported "agree" or "strongly agree" with the 33 statements addressing leadership life skills.

3. Analysis of the 33 individual questions revealed that the statement, "I learn from others" received the highest number (116) of "strongly agree" responses. Fifty-three percent of the participants felt they learn from others. It may be concluded that peer to peer teaching is an effective means of teaching teens.

4. Participants had a positive attitude toward diversity and acceptance of others, $45.2 \%$ and $38.9 \%$ responded "agree" or "strongly agree" respectively to the statement, "I accept other people as they are." Similarly, $46.6 \%$ responded "agree" and $41.2 \%$ responded "strongly agree" to the statement, "I can get along with others who are different than me." This supports the research of Kirby (1989), and Billig (2000). Woyach's (1996) model of a successful leadership education program also includes attention to diversity and sensitivity to other cultures.

5. Forty-eight percent (105) of the participants responded "strongly agree" with the statement, "I can make a difference in my community." Astin et al. reported similar attitudes. This also parallels the Independent Sector's findings (2003), where the benefits of youth involvement in service activities included having an impact and making a difference.

6. The subscale Creative Problem Solver revealed that participants were not positive in their attitudes of this characteristic. Eleven percent of the respondents rated their selfperceived leadership skill in this area below average. Of the remaining $89 \%$, only $15 \%$ strongly agreed with the five statements in this subscale. This finding parallels Stafford's 2001 research, where Creative Problem Solver skills were rated moderately low by study participants using a similar instrument. It may be concluded that teens have either not 
had the opportunity to practice creative problem solving or have not been taught how to do so.

The third objective sought to describe whether having a reflection component as part of the service project makes a greater impact than a service project without reflection in the development of leadership life skills. The analysis was conducted by computing an independent samples t-test comparing the means of each of the five subscales: Effective Team Skills, Creative Problem Solver, Personal Leadership Development, Self-Directed Learner and Contributor to Community.

No significant difference between the reflection (treatment) and no reflection (control) group was found. The presence of a reflection component in the service activity did not significantly increase perceived leadership life skills in the participants. This finding does not support Stafford's 2001 findings, where reflection immediately following the activity significantly affected the means for Contributor to Community. Nor does this finding support the Standards Committee of the Alliance for Service-Learning (Close Up Foundation, 1995) which states that preparation and reflection are critical to a successful service-learning program.

The fourth objective was to describe whether a relationship exists between the youth's service experience, their self-perceived leadership life skills and selected demographic characteristics. The service experience refers to whether the service activity was more than $50 \%$ direct contact or more than $50 \%$ indirect contact or no service activity. Service experience also refers to the number of hours a youth contributes to service activities on a monthly basis. Youth reported their prior service hours as $0,1-3,4-6,7-9$ or 10 or more hours per month.

Self-perceived leadership life skills refer to the five dependent variables: Effective Team Skills, Creative Problem Solver, Personal Leadership Development, Self-Directed Learner and Contributor to Community. Selected demographics include gender, age, and treatment.

A multiple analysis of variance (MANOVA) was used to determine the differences between the five dependent variables and selected independent variables. The use of MANOVA reduces the chance of a Type I error when trying to determine if several groups differ on more than one dependent variable (Gall, Borg \& Gall, 1996). The results of data analysis for objective four are as follows:

1. A significant difference was seen in service type and service hours; gender, age and treatment did not show a significant difference on the development of leadership life skills, this was determined with the MANOVA. Schine (1990) makes a case that reflection is not the only factor important to the success of a service-learning program. The type of service, whether there was direct or indirect contact in the activity plays a critical role, as this research also found.

2. Gender and age did show significance in the area of helping others in the National 4-H Impact Assessment Project, (2001. Females reported higher mean scores than males. Younger youth reported higher mean scores than older youth.

The fifth objective of the study was to describe whether participation in 4- $\mathrm{H}$ and youth development activities has an impact on self-perceived leadership life skills. An independent samples t-test was used to compare the means on the five leadership life skills between 4-H members (75\%) and non-4-H members (25\%). Results of the data analysis are as follows:

1. The mean for each of five leadership skills was higher for non-4-H members than 4-H members. This finding is not supported by other research in the area of 4-H leadership 
life skills development (Boyd, Herring \& Briers, 1992, Howard, 2001, Rodriguez, Hirschl, Mead, \& Goggin, 1999, Astroth, 2002, \& Ledoux, 1997).

2. Personal Leadership Development was statistically significantly different between the two groups.

\section{Implications}

Participants in the study generally perceived their leadership life skills to be above average. 4-H participants historically are exposed to many leadership training opportunities and may have under-rated their leadership skills; while, non-4-H participants may have over-rated their leadership skills.

The presence or absence of a reflection component in the service activity did not have a significant effect on the perceived leadership life skills of participants. The measurement of a one-time service activity may not be enough to change the participant's level of leadership life skills. The participants' assessments of their current perceived leadership life skills were already at a high level due to the nature of the activity. The reflection component alone may not impact leadership life skills, other factors may need to be considered as suggested by Schine (1990). Linking the service activity specifically to a leadership curriculum and connecting the two during reflection activity may serve to identify an impact.

The type of service and the hours of service completed on a monthly basis, did however, have a significant impact on perceived leadership life skills. There is an implication that participants involved in activities that require direct contact with service recipients will perceive their leadership life skills to be higher. Similarly, those youth who participate in 7-9 or more hours of service on a monthly basis will have higher perceptions of their leadership life skills.

\section{Recommendations for Action}

1. Utilize curricula that allows teens teaching teens, as this research showed the most frequent positive response. Fifty-three percent "strongly agreed" for the statement, "I learn from others." Forty-nine percent responded "agree" to the statements, "Helping others increases my awareness of other's needs," and "Serving others helps me grow as a leader."

2. Include service activities in 4-H and youth programming, with the goal of youth participating seven or more hours on a monthly basis. This research indicated that as the hours of youth service increases, on a monthly average, the perceived leadership life skills rating also increased.

3. Encourage service activities that provide direct involvement with the recipients versus indirect involvement. "Bake and take" is nice, but one to one service yields greater benefits for the provider and the recipient. Direct service activities showed significantly different impact over Indirect service activities in this research.

4. Link 4-H project areas to the service activity; research supports the idea that the significance of the activity is increased when there is relative value seen by the service provider.

5. Utilize an evaluation instrument or methodology that includes more than self-reporting. 


\section{References}

Astin, A.W., Vogelgesang, L.J., Ikeda, E.K., \& Yee, J.A. (2000). Executive summary: How service learning affects students. Los Angeles, CA: Higher Education Research Institute.

Astroth, K. (2002). Montana 4-H research summary. Bozeman, MT: Montana State University.

Billig, S.H. (2000). Research on K-12 school-based service-learning: The evidence builds. Phi Delta Kappan, 81(9), 658-664.

Boyd, B.L., Herring, D.R., \& Briers, G.E. (1992). Developing life skills in youth. Journal of Extension, 30(4). Retrieved September 9, 2002 from

http://www.joe.org/joe/1992winter/a4.html

Close Up Foundation. (1995). Standards of quality for school-based and community-based service-learning. Alexandria, VA: Alliance for Service-Learning in Education Reform.

Cohen, J. (1988). Statistical power analysis for the behavioral sciences ( $2^{\text {nd }}$ ed.). Hillsdale, NJ: Lawrence Earlbaum Associates.

Corporation for National and Community Service. (2006). Educating for Active Citizenship: Service-Learning, School-Based Service, and Civic Engagement. http://www.nationalservice.gov/about/role impact/performance research.asp

Gall, M.D., Borg, W.R., \& Gall, J.P. (1996). Educational research: An introduction. (6 ${ }^{\text {th }}$ ed.). White Plains, NY: Longman Publishers USA.

Howard, J.W. (2001). Impact assessment of the Texas 4-H and youth development program. Unpublished doctoral dissertation, Texas A\&M University.

Independent Sector. (2003). Engaging youth for lifelong service: Findings and recommendations for encouraging a tradition of voluntary action among America's youth. Washington, DC.: Independent Sector.

Kirby, K. (1989). Community service and civic education. Bloomington, IN: ERIC Clearinghouse for Social Studies/Social Science Education. (ERIC Document Reproduction Service No. ED 309135).

Ledoux, M. (1997). New York State 4-H youth community service guide. Ithaca, NY: Cornell University, College of Human Ecology.

National 4-H Headquarters Cooperative State, Research, Education and Extension Service, U.S. Department of Agriculture website. (2006). Retrieved October 21, 2006 from http://4htools.cals.arizona.edu/assessmentTool.cfm

National 4-H Impact Assessment Project. (2001). Prepared and engaged youth. Washington, DC.: United States Department of Agriculture, Cooperative State Research, Education and Extension Service. 
National Center for Education Statistics. (1999). Service-learning and community service in K-12 public schools. Statistics in Brief. U.S. Department of Education, Office of Educational Research and Improvement, NCES 1999-043: Washington, DC.

Rodriguez, E., Hirschl, T.A, Mead, J.P., \& Goggin, S.E. (1999). Final Report. Understanding the difference 4-H Clubs make in the lives of New York youth: How 4-H contributes to positive youth development. Ithaca, NY: Cornell University.

Schine, J. (1990, Spring) A rationale for youth community service. Social Policy, 00377783, 20, (4). Retrieved January 14, 2003 from http://web10.epnet.com/citation.asp

Stafford, J.R. (2001). The effect of service-learning in developing leadership life skills. Unpublished Master's thesis. Texas A\&M University, College Station, TX.

Woyach, R.B. (1996, Spring). Five principles for effective youth leadership development programs. Leadership Link, pp. 1-2. Columbus: The Ohio State University.

(C) Copyright of Journal of Youth Development $\sim$ Bridging Research and Practice. Content may not be copied or emailed to multiple sites or posted to a listserv without copyright holder's express written permission. However, users may print, download or email articles for individual use. 